\title{
Philip Morris's website and television commercials use new language to mislead the public into believing it has changed its stance on smoking and disease
}

\author{
Lissy C Friedman
}

Tobacco Control 2007;16:e9 (http://www.tobaccocontrol.com/cgi/content/full/16/6/e9). doi: 10.1136/tc.2007.024026

See end of article for authors' affiliations

Correspondence to: Lissy C Friedman, Public Health Advocacy Institute, 102 The Fenway Cushing Hall, Room 117, Boston, MA 02115, USA; lissy@tplp.org

Received 25 October 2007 Accepted 25 October 2007

\begin{abstract}
Objectives: This paper analyses Philip Morris's evolving website and the legal strategies employed in its creation and dissemination.

Methods: Internal tobacco documents were searched and examined and their substance verified and triangulated using media accounts, legal and public health research papers, and visits to Philip Morris's website. Various drafts of website language, as well as informal discussion of the website's creation, were located in internal Philip Morris documents. I compared website statements pertaining to Philip Morris's stance on cigarette smoking and disease with statements made in tobacco trials.

Results: Philip Morris created and disseminated its website's message that it agreed that smoking causes disease and is addictive in an effort to sway public opinion, while maintaining in a litigation setting its former position that it cannot be proved that smoking causes disease or is addictive.

Conclusions: Philip Morris has not changed its position on smoking and health or addiction in the one arena where it has the most to lose-in the courtroom, under oath.
\end{abstract}

l n 1999, Philip Morris, Inc, the largest and most powerful multinational cigarette manufacturer in the world, launched an advertising campaign publicising its new website, which contained information about the harmful effects of smoking. The website included an extraordinary statement that appeared to admit that Philip Morris now believed that the issue of causation between smoking and disease had been proved. It referred viewers to various governmental and public health resources, including the Surgeon General's Report and the Centers for Disease Control and Prevention, as well as major public health advocacy organisations such as the American Cancer Society. Moreover, Philip Morris appeared to admit that smoking is addictive, conceding that quitting can be difficult, and referring website users to various cessation resources.

The initial reaction from the press, the public and plaintiffs' litigators was a mixture of guarded optimism, scepticism and incredulity. Was Philip Morris raising the white flag and ready to concede that its products caused the sickness and death of its consumers for more than half a century? Would this perceived concession cause a seismic shift in the products liability landscape, resulting in possibly thousands of plaintiffs' verdicts that could bankrupt the company? Did Philip Morris intend to set an example for the rest of the tobacco industry and take responsibility for its past bad conduct? A recent study by Balbach et al examined tobacco industry trial testimony and how the tobacco industry misuses its website and advertising campaigns to be a source of specious information for consumers and the public. ${ }^{1}$ The study found that the information was conveyed without taking any responsibility for the quality, veracity or accuracy of that information, thus allowing the tobacco industry's witnesses to claim disingenuously that consumers made an "informed choice" to smoke. Balbach et al concluded that this places the "moral responsibility" on the smoker: if the smoker ends up being injured as a result of smoking cigarettes and sues for compensation, then the tobacco industry defendant can claim that the consumer was fully informed yet made the wrong choice, thus shifting the blame away from the tobacco products and their manufacturers to the consumer.
This paper will focus on Philip Morris that, of all the major tobacco companies, has made the most visible use of its website with an accompanying advertising campaign supporting its website's message, at www.philipmorrisusa.com. Extending beyond the specific information provided on the tobacco industry's websites and the industry's fluid definition of "truth" and "information," as discussed by Balbach et al, this paper will focus less on the substance of Philip Morris's website and more on its litigation strategy and how it hoped to use the website to manipulate and deceive juries to influence the outcome of litigation. The paper will demonstrate through trial testimony how plaintiffs' lawyers repeatedly revealed the deceptive nature of this campaign. It will examine how this litigation strategy may have influenced the verdicts of cases, with several juries finding against Philip Morris and awarding huge punitive damages awards, and in one case a federal judge finding that Philip Morris, along with its tobacco company codefendants, were racketeers. Unmasking Philip Morris's deceptive strategy that drove the creation of its website has been and should continue to be a useful tool for plaintiffs' litigators in holding Philip Morris and other tobacco companies accountable in the arena where it counts most-the courtroom.

\section{METHODS}

Internal tobacco industry documents were located at tobacco document archive websites, including www.tobaccodocuments. org and http://www.legacy.library.ucsf.edu. Search terms to find relevant documents included singly and in combination the words "website," "we agree," "admission," "corporate responsibility," and "we've changed." Names attached to internal memos regarding the creation and publicity of the website, such as Ellen Merlo, Steven Parrish and Michael Szymanczyk, were also combined with the initial search terms using the snowball method to generate additional search terms and documents. Documents were reviewed iteratively, comparing statements made in depositions and trial testimony with language in internal company documents, website language and media accounts. Trial depositions and testimony were 
obtained from the Tobacco Deposition and Trial Testimony Archive, located at http://tobaccodocuments.org/datta. Information about jury verdicts and damages awards were verified through The Tobacco Products Litigation Reporter, backgrounders from the Tobacco Products Liability Project at www.tobacco.neu.edu and other published sources.

\section{The evolution of Philip Morris's website}

In July 1999, after a series of litigation and public relations setbacks, Philip Morris's chief executive officer, Geoffrey Bible, revealed to a group of stock analysts that his company was going to be taking "immense" steps to burnish its image to improve its chances in litigation, stating that the company would become "more visible, more accessible, and responsive." 2 Referring to recent litigation losses, Philip Morris's vicechairman and general counsel, Murray Bring, said that the company planned "to make significant changes in our litigation strategy to address juror anger," though neither Bring nor Bible was specific about how Philip Morris intended to accomplish these aims.

On 13 October 1999, Philip Morris launched a website that addressed the potential dangers of smoking, including such issues as the causation between smoking and disease, and the addictive nature of cigarettes. ${ }^{3}$ The evolution of the website's text is illuminating. Initially, the website's language stated:

\section{Cigarette Smoking and Disease in Smokers: There is an overwhelming medical and scientific consensus that cigarette smoking causes lung cancer, heart disease, emphysema and other serious diseases in smokers. Smokers are far more likely to develop serious diseases, like lung cancer, than non- smokers. There is no "safe" cigarette. These are and have been the messages of public health authorities worldwide. Smokers and potential smokers should rely on these messages in making all smoking-related decisions. ${ }^{4}$}

The website contained links to public health information such as the US Surgeon General's Report and to public health advocacy agencies such as the World Health Organization, the Centers for Disease Control and Prevention and the American Cancer Society. Although the website addressed various other topics such as youth smoking prevention, secondhand smoke and cigarette marketing practices, for the purposes of this article, the focus will be on only two of the website's topics: (1) smoking and disease issues, and (2) cigarettes and addiction.

In tandem with the release of the website, Philip Morris rolled out an extensive television advertising campaign to publicise it. One of the main television advertisements directly addressed the issue of smoking and disease. It stated:

Cigarette smoking is addictive and causes serious diseases. Smokers are far more likely to develop serious diseases like lung cancer than non-smokers. There is no safe cigarette. At PhilipMorrisUSA.com you can find this and other information on the serious health effects of smoking and links to reports from public health authorities including links to sites that can help smokers quit. For more information visit PhilipMorrisUSA.com. ${ }^{5}$

A press release from Philip Morris announcing the website's creation stated:

[T] he Philip Morris family of companies will expand its efforts to communicate more openly with the public about its people, products and values through an Internet website and national television advertising. Beginning today, these tools will help tell the company's story and underscore its desire to engage the public in a more constructive way. . . . The new website and television commercials will enable Philip Morris to reach even more people. ${ }^{6}$

Philip Morris publicised its website by printing the address on its cigarette packages and point-of-sale advertisements, and providing brochures containing the website information to retailers, its customer database, and eventually to readers of major newspapers with "freestanding inserts" duplicating the website's information. ${ }^{7}$ It also began to run television and radio commercials that conveyed the information stated on its website. $^{8}$ Only a year later, Philip Morris was forced to recognise the scepticism about its motives for launching the website and accompanying PR campaign, and changed the website's language.

\section{Philip Morris's public relations not able to overcome} the public's scepticism

Philip Morris's website roll-out and initial public relations campaign were less than successful in convincing the press and public health advocates that its statements constituted more than a clever re-wording of its original entrenched position that there is no probative link between smoking and disease. This was reflected in an interview with Philip Morris's then senior vice-president for corporate affairs, Steven C Parrish, by Ted Koppel on the TV programme "Nightline" on the day the website went live. Koppel forced Parrish to admit that even though the website appeared to concede causation and addiction, Philip Morris's stance in smoking and disease litigation would not change and the company still would contest these issues. ${ }^{9}$ The hostile questions posed by reporters embodied the public's scepticism of the tobacco industry's motivations, reflecting the press and the public's new analytical sensibilities that were formed based on numerous factors, including the release of thousands of internal tobacco industry documents, revelations from at least one high profile whistleblower, Jeffrey Wigand, and possibly by the ordeal of a presidential impeachment partially premised on the president's careful parsing of words in a legal deposition.

Finally, after almost a year of opposition from public health advocates, bad press, and pressure from plaintiff attorneys' tenacious cross-examination in cases brought by injured smokers or their survivors, Philip Morris refined its official statement on its website. In October 2000, it was modified to include the phrase "we agree with the overwhelming medical and scientific consensus that cigarette smoking causes [various diseases ] . . . " 10

\section{Philip Morris's original website on trial}

During the course of various legal proceedings before the addition of the phrase "we agree" in October of 2000, questions were posed about the website's language. The evasive and equivocal answers Philip Morris's witnesses gave revealed the weakness in the company's initial choice of words for its website, which eventually prompted the website's language to be altered.

Before the change in the website's language, witnesses for Philip Morris had trouble making the transition and embracing the new strategy that the original website created, and showed some discomfort in echoing its message. In February of 2000, James Morgan, a retired Philip Morris president and CEO, testified in a deposition in the case of Whiteley $v$ Raybestos Manhattan Inc, et al, brought by an individual who had smoked Philip Morris's cigarettes and died of smoking-related illness. ${ }^{11}$ Morgan was asked about whether the website's language 
represented a change in the company's position regarding smoking and disease and in relation to addiction. The plaintiff's attorney read portions of the website and asked, "[D]id you have an impression as to whether that represented a change in the public position of Philip Morris?" Morgan replied, "Well, I think it was a modification ... So it's hard for me to characterize the degree of change. It was definitely a new set of words, but whether or not it reflected a change in the company's view on addiction is hard for me to characterize." Morgan's testimony, which hedged at acknowledging that tobacco causes disease and addiction, seems to imply that the company's new rhetoric might have been employed for legal strategic and public relations purposes and that the website's rhetoric was simply an example of style over substance.

On 22 March 2000, also in Whiteley $v$ Raybestos-Manhattan, Inc, et al, the plaintiff's lawyer cross-examined Ellen Merlo, Philip Morris's senior vice-president of corporate affairs. Merlo, who had principal responsibility for the creation of the company's website, was asked about why the website's language seemed to be hedging. ${ }^{12}$

- Q. Nowhere do you say in that website that Philip Morris agrees with the position taken by the medical and scientific community as to the diseases that cigarette smoking causes?

- A. We don't agree or disagree with it. We present the information and we encourage people to rely on that information in making that decision as to whether or not they should smoke.

This answer apparently did not mollify the jury, which found for the plaintiff and awarded $\$ 1.75$ million in compensatory and $\$ 20$ million in punitive damages. ${ }^{13}{ }^{14}$ (This verdict later was retried because of a technicality and the jury awarded a greater amount of compensatory damages, \$2.4 million, but was split on whether to award punitive damages and therefore none were ordered. ${ }^{15}$ )

The move towards modifying the website's language to include the phrase "we agree" was foreshadowed in a May 2000 deposition of Michael Szymanczyk, CEO of Philip Morris, in the case of Engle $v$ RJ Reynolds Tobacco Company, et al, a massive class action suit seeking damages for all Florida smokers. Szymanczyk was interrogated about whether Philip Morris's website statements amounted to a legal admission that it had been proved scientifically that cigarette smoking causes lung cancer and other diseases. ${ }^{16}$ Firstly, the plaintiffs' attorney pressed Szymanczyk about the exact definition of "scientifically proven." Szymanczyk was reluctant to equate the beliefs of public health officials with facts that are "scientifically proven."

- Q. As the CEO of Philip Morris, Inc, has it been scientifically proven that cigarette smoking causes lung cancer and other diseases?

- A. I think that would depend on your definition of scientifically proven. If your definition of proof is, as I mentioned, strong statistical evidence, then scientists formed a consensus about that evidence and made a decision about what it means, which is what's been done in the case of tobacco and the public health authorities in this country. If you're talking about scientifically proven being a determination of the mechanism by which smoker [sic] constituents ... cause disease, to the best of my knowledge that mechanism has not yet been identified or that chain of events has not yet been identified. I think there's scientific consensus in general in the scientific community that that's a true statement.

Then the questioning shifted to whether the company's statement on its website was trying to skirt the issue of whether it agreed with those public authorities on whose opinion the website recommended cigarette consumers should rely. The plaintiffs' attorney asked, "Has Philip Morris ever said on its website or anywhere else that we as a company agree with that consensus?" and Szymanczyk conceded, "We have not." He offered the rationale that the 1998 Master Settlement Agreement with 46 states bound the cigarette manufacturers to agree with public health officials and stated:

Because we agreed there would be only one voice with members of congress [sic] so we have stuck with that agreement and we provided the information that supports what the public health community says on this subject and we do it in a very clear fashion and, in fact, with a lot of access to additional information from the public health authorities. That's how we have chosen to operate.

Although this testimony was not used at trial, it laid the groundwork for plaintiffs' lawyers in future cases who did make use of this line of questioning in trials as described in the next section.

The website language is changed to add "we agree" After the website language changed, a crucial question arose about what effect this would have on Philip Morris's litigation strategy and whether plaintiffs would be able to use the change to their own advantage. The answer to the question of whether Philip Morris intended to make an admission of facts regarding smoking and disease and addiction became clear when plaintiffs' counsel in several smoking cases began to file motions asking that the text of Philip Morris's website be judicially noticed or taken as an admission of fact. Immediately upon publication of the company's original website language, in October 1999, plaintiff's counsel in Jones $v$ Brown \& Williamson Tobacco Co, et al served a Request for Admission to Defendant Philip Morris, asking that Philip Morris admit or deny each statement. The statements quoted or paraphrased those on its website:

- Please admit that there is no "safe" cigarette.

- Please admit that cigarette smoking causes cancer, heart disease, emphysema and other serious diseases.

- Please admit that there is an overwhelming medical and scientific consensus that cigarette smoking causes lung cancer, heart disease, emphysema and other serious diseases in smokers.

- Please admit that cigarette smoking is addictive, as that term is most commonly used today. ${ }^{17}$

Philip Morris's response was five pages of general and specific objections that objected to the use of such words as "cancer," "heart disease" and "other serious diseases."18 Further, it objected to the use of the term "causes" on the basis that it was "vague and ambiguous," despite the fact that this language derived specifically from its own website. In a subsequent news story, the plaintiff's attorney, Howard Acosta, recalled that before filing his motion, he contacted one of Philip Morris's attorneys asking if they were going to "admit in court what it appeared to admit on its Web site[.]" Acosta recounted the attorney's response: "He said, 'You'll get two pages of our standard sharply written objections."'19

In Hazeltine $v$ Philip Morris, Inc, et al, ${ }^{20}$ and Hiscock $v$ RJ Reynolds Tobacco Co, et al, ${ }^{21}$ two smokers' cases filed in October 1999, the plaintiffs filed a Request for Judicial Notice as to the Health Consequences of Smoking and the Addictive Potential of Cigarettes. The Hiscock motion also was accompanied by a newspaper article covering the release of the new website. 
Philip Morris filed an objection in both Hiscock and Hazeltine disputing that its website statements amounted to "facts" that could be judicially recognised, noting that "Plaintiff's proposed 'facts' are clearly in dispute, and accordingly, this Court should deny Plaintiff's Request." Again, in the only context where Philip Morris can be held legally responsible-in the courtroom-the company asserted a position clearly at odds with its public relations campaign.

After adding the "we agree" language to the website, Philip Morris went on the offensive, attempting to convince jurors in products liability suits that the revised website language proved that Philip Morris had changed its position on smoking and disease. In the closing arguments on whether punitive damages should be awarded to the plaintiff in Bullock $v$ Philip Morris, Inc, a 2002 California case brought on behalf of a smoker suffering from injuries which allegedly were the result of smoking Philip Morris cigarettes, Philip Morris's lawyer summed up Philip Morris's current stance on the question of smoking and causation. $^{22}$

First, Philip Morris now acknowledges without reservation, without qualification, without any hesitation whatsoever that the overwhelming medical consensus, medical and scientific consensus in the world is that cigarette smoking causes disease and is addictive; without qualification.

But the fact of the matter is, publicly and unequalifiably [sic]-remember during the course of the trial we showed you this exhibit, 7070. This is Philip Morris' [s] website called "Health Issues for Smokers." A version of this website was put out by Philip Morris in 1999 before this lawsuit was filed. The one that you saw before in this case and this one says, "We agree with the overwhelming medical and scientific consensus," the only difference between this one and the one that was put out in 1999 is the words "We agree," because there were people who thought they should say "We agree," not just that there is an overwhelming consensus. Either way, the point is that this public acknowledgement that smoking causes lung cancer and is addictive is known all over the world. It was widely publicized. It was publicized here in Los Angeles in the LA Times and on television stations. It has been written about in newspapers and magazines. Mrs Bullock knows about it.

You found that Philip Morris should have done this a long time ago, and you are right; but the fact of the matter is they do today. How do you think, even if they wanted to, they could ever take it back?

The jury was not persuaded by this line of argument, assessing $\$ 850000$ in compensatory damages and \$28 billion in punitive damages against Philip Morris, ${ }^{23}$ which the court later reduced to $\$ 28$ million. ${ }^{14}$

\section{Why Philip Morris gave the appearance of changing its stance on the smoking and disease issue-societal alignment strategy}

Philip Morris was aware as far back as 1992 that a change in its stance on causation and addiction could improve its image with the public in general, its consumers and hopefully juries, provided it was done artfully and carefully, while not conceding any legal liability. In 1992, Steven C Parrish, then Philip Morris's vice-president, secretary and general counsel, circulated a document setting forth goals for the year 2000 and strategies for attaining not only corporate stability but financial growth. ${ }^{24}$ The memo listed as a "must-have goal" destigmatising the tobacco industry's products liability litigation so that it would be viewed like any other corporation selling risky products, such as prescription drugs sold by Pfizer or consumer goods sold by Proctor and Gamble.

In May 2001, before Philip Morris's shift to the "we agree" language on its revised website, in Boeken $v$ Philip Morris, Inc, a smoker's lung cancer case, Ellen Merlo explained the reason for Philip Morris's efforts at improving its corporate image, which she claimed culminated in a mission statement dedicated to clearer communication with the public:

It became clear to ... us at Philip Morris that we were out of alignment with society and that we needed to bring about a culture change within Philip Morris, USA, and that by creating a mission, set of core values and some very specific measurable goals, it would be easier for us to communicate to every employee what the expectation was going forward, the way we were going to conduct our business. ${ }^{25}$

Plaintiff's attorney Mike Piuze questioned Merlo about whether the company's new website and ad campaign were merely an attempt at putting "a more positive face on the corporation." Merlo responded, "Well, it was-it was part of our trying to be more open to communicate more openly with consumers and society, yes. . . I think that's one of the goals. But it was also to let people come to the website and learn more about Philip Morris, its products, its policies and positions."

A 1999 internal memo by Steven Parrish called Philip Morris's new strategy to improve its image "societal alignment," language echoed in Merlo's testimony in Boeken. ${ }^{26} \mathrm{He}$ described it as "a short-hand way of saying that we want to be and be seen as a responsible manufacturer and marketer of our products." He emphasised, however, the "be seen" part, stating that " $[\mathrm{H}]$ ere again, we cannot be intuitive. We must use research to carefully determine, market by market-what we need to do and say to be seen as responsible business people."

Another tobacco executive, Jay Poole, Philip Morris's regional manager for government relations, explained the societal alignment concept in February 2000 to a group of Michigan dairy owners. ${ }^{27}$ He stated:

We learned, at great cost, that making great products, doing great marketing, and building great brands such as Kraft, Miller and Marlboro, no longer add up to a great public image. Maybe it used to. But that's changed. We were slow to notice that change. .. . [The tobacco industry] hit a brick wall and it caused our image to crumble. And a broken image has a far-reaching impact on every aspect of our business. A while back, perhaps some of you saw the Business Week article that called Philip Morris "America's most reviled company." . . . If our corporate image were the results of good business, good people and successful products, we'd be glowing. But the general public cares about more than just that; they care about the company's honesty and integrity.

Poole recalled Philip Morris's previous strategy of ignoring public opinion and adopting the strategy that "within the tobacco industry you don't give an inch. ... And on it went. For years. The tobacco industry blocked every change at every juncture. Or tried to." Poole acknowledged:

We want to do what it takes to make peace with society. . . . We used to have the attitude of "fight because we're right." Well we found that facts and sound science don't always win the game either. Isn't that a sad statement. So part of our 
new attitude has also meant aligning with others who face the same issues that we do.

Poole's speech illustrates a move towards changing the message the company delivered to the public in the hope that its products could be viewed to be as harmless as other consumer products, but again the emphasis is on style over substance, which is what the societal alignment strategy appears to have been about.

Philip Morris's original website stance on causation and addiction was road-tested in the course of litigation and found to be wanting in its mission to demonstrate that the company was more in alignment with society on the issue of smoking and disease. Various tobacco executives testified in products liability litigation about the company's decision to change its message, if not its actual beliefs, about whether its product was harmful. Plaintiffs' lawyers in smoking cases used crossexamination to expose the inconsistencies in its arguments and reveal the disingenuous nature of its new rhetoric.

Despite the website's language and Philip Morris's efforts at being more forthcoming with its societal alignment message, tobacco defence witnesses still found it difficult to square the position their website took (smoking causes disease) with the stance they were taking on the stand (there is no proof that smoking causes disease). In his May 2000 deposition in Engle, ${ }^{16}$ Philip Morris CEO Michael Szymanczyk, after hedging on what the definition of "scientifically proven" is in the context of the new website language, was asked why Philip Morris apparently had capitulated to the prevailing consensus that smoking causes disease. Mr Szymanczyk claimed that the revelation came after the tobacco industry faced lawsuits by 46 state attorneys general in the late 1990s, admitting that "somewhere in there there is a pretty good message that you need to understand what's not working right and where you're out of step with what these representatives of the people in this country expect of you."

In May 2001, in Boeken v Philip Morris, Inc, it became evident that despite defence witnesses avowing Philip Morris's dedication to corporate responsibility and greater communication with its consumers and the public in general, the company nevertheless was yielding no ground when it came to legal liability for the effects of smoking on its consumers. Ellen Merlo's testimony reveals fissures between the company's message and the reality of its entrenched litigation strategy. ${ }^{28}$

- Q. Did I hear you say this morning that your cigarettes are dangerous products that cause disease?

- A. Yes, you heard me say that.

- Q. Kill people?

- A. They cause disease.

- Q. Kill people?

- A. They may.

- Q. Yes?

- A. That's what I just said, they may, yes. I said they are dangerous products, they cause disease.

- Q. I know. I am just trying to get you to go the next step, just acknowledge the fact that Philip Morris's cigarettes kill lots of people.

- A. It certainly is possible that Philip Morris's products kill people. Cigarettes are dangerous products that cause disease and some people die from that disease, yes.

Moving from the issue of causation to addiction, the plaintiff's attorney attacked the company's latest position on whether cigarettes are addictive. This colloquy between plaintiff's attorney Mike Piuze and Merlo illustrates Philip
Morris's fence-straddling approach between societal alignment and avoiding legal liability.

- Q. And Philip Morris's current web site . . . One of the things it says has to do with addiction; right?

- A. That is correct.

- Q. What does it say?

- A. It says that we believe that cigarette smoking is addictive.

- Q. . . First of all, what's up on the web site now, isn't that really a marketing decision by Philip Morris to put that on the web site now?

- A. No, it was not a marketing decision at all.

- Q. When did you figure out, and see, I have to ask this of you corporately, I guess, when did you figure out that nicotine was addictive?

- A. Well, I believe our position on nicotine over the years has evolved and, again, as with our position on causation, we were really adhering, I think, to what was scientifically accurate and correct in the way we were interpreting addiction and not talking about it as it was more widely accepted within society. And therefore, we talked more about the pharmacological effects of nicotine, et cetera, and on that basis, said that nicotine was not addictive. I think, as the public health community uses that term, and as society accepts that term our position on addiction has evolved as well.

- Q. When did you figure out nicotine was addictive?

- A. Our position changed on addiction within the last few years.

- Q. You see, I am not asking about your position, I am asking about your knowledge, when did Philip Morris, if you don't know, that's okay, but when did Philip Morris know that smoking was addictive?

- A. Well, again, I think it came down to the way you define the term addictive. And by the classic definition of the word addiction, while I believe we, at Philip Morris, believe that it certainly was habit forming, I think we believe that it was very difficult for many people to quit, we were not using the term "addiction" as it is now commonly used in society. And we have changed our position on addiction to bring it more in line with the way society defines the term today.

Finally, Attorney Piuze asked a question aimed at exposing the fallacy in Philip Morris's assertion that it could agree with the general consensus view of public health officials that smoking causes disease and is addictive, while simultaneously maintaining a viable litigation strategy.

- Q. You just said in your last long answer, and I believe I heard you say a couple times yesterday, that you were changing what you, corporately, were changing what you were saying as a result of what society thought. Did I get that right?

- A. I think what I said, it's close to what I said, is I think that we wanted to bring ourselves more into societal alignment, as a company, and, yes, that we were changing the way we were dealing with many issues.

- Q. Why not deal with the issues based on science rather than upon what society thought?

- A. Well, I think we had been dealing with the issues based on science. I think we were being precise and accurate and reasonable as far as what science told us, which is, we didn't know [sic] mechanism, we didn't know constituents and we were being very precise in our position as a result of that. But that was somewhat out of line with what society believed and it was certainly out of line with the conclusions of the 
public health community and therefore we did change our position. So I believe we were being very precise in our position.

In the final analysis, the jury apparently was not impressed with Philip Morris's new and more conciliatory stance on causation and addiction, and awarded the plaintiff Judy Boeken $\$ 5.5$ million in compensatory damages and \$3 billion in punitive damages (an amount later reduced on appeal). ${ }^{14}$

The motivations for Philip Morris putting forth an apparently different message appear to come less from a place of sincere desire to be forthright with its customers and the general public, but rather to give the appearance of corporate responsibility in order to impact the litigation environment favourably for itself. Trial testimony shows that the changes Philip Morris made with its website were superficial and strategic, not conciliatory or revelatory. Philip Morris had two strong motivations for putting forth a new rhetoric: (1) to avoid huge punitive damages in individual and class action lawsuits; and (2) to stave off a negative verdict in the US government's massive racketeering lawsuit against the major tobacco manufacturers, including Philip Morris.

\section{Punitive damages - "we've changed"}

Philip Morris may have hoped its website and media campaign would influence juries to convince them that the company has changed and that it is no longer engaging in bad behaviour in order to avoid the huge punitive damages. The strategy seems to be failing for Philip Morris more frequently than it succeeds, though it made progress in the Whiteley case, in which, on retrial, the jury was split on whether to award punitive damages and therefore none were awarded..$^{15}$ There have been several cases since the launch of Philip Morris's website in which juries awarded huge amounts of punitive damages. In the Boeken case, for example, the jury awarded the plaintiff $\$ 3$ billion in punitive damages, an enormous sum in comparison with the $\$ 5.5$ million award of compensatory damages. In the Bullock case, the jury awarded $\$ 28$ billion in punitive damages. On the class action front, the fight for the hearts and minds of juries is also tilting in favour of the plaintiff, as in Engle, where the jury awarded an unprecedented punitive damages verdict of $\$ 145$ billion. While these punitive damages verdicts reflect the juries' appreciation of Philip Morris's culpability, no such award has survived the appeals process intact, either being reduced, as in Bullock ${ }^{29}$ and Boeken, ${ }^{30}$ or overturned altogether, as in Engle. ${ }^{31}$ Nevertheless, the original jury verdicts do send a message to Philip Morris that the juries may doubt the sincerity of its website message and its accompanying advertising campaign.

Reading through trial transcripts and depositions involving smokers' cases in the last few years, it is clear that Philip Morris's message for juries is "we've changed." For instance, in Whiteley $v$ Raybestos-Manhattan, Inc, et al, a year 2000 case, when defendant's counsel asked Philip Morris's senior vice president of corporate affairs Ellen Merlo whether the jury should award punitive damages for the purpose of preventing future bad conduct by Philip Morris, she replied that it should not. ${ }^{12}$ Under direct examination by defence counsel, she explained her position:

\footnotetext{
I believe we certainly have gotten the message. We understand how people have perceived us in the past. We're working very hard to change our culture and the way we do business. And I believe now what we need is an opportunity to prove to people our commitment to living our mission and our values in the future, and that's what the need is the time to prove our sincerity and our commitment. ${ }^{32}$
}

Apparently unswayed by Merlo's mea culpa, the jury in Whiteley awarded \$20 million in punitive damages. This verdict was later overturned based on unrelated technical grounds, and in the next trial, punitive damages were not awarded because of a jury split, which nevertheless showed more jurors in favour of punitive damages than not on the question of whether Philip Morris and its co-defendant RJ Reynolds were guilty of malice in their conduct related to the false promises to Ms Whiteley. ${ }^{15} 33$

In a year 2000 deposition given by Philip Morris CEO Michael Szymanczyk in the Engle case, the plaintiff's attorney asked Szymanczyk whether during the punitive damages phase of the trial the defendants intended to introduce evidence about how the company had changed its ways. ${ }^{16}$

- Q. I have heard in the courtroom that one of the main presentations of the tobacco companies in the punitive damages phase of the Engle class action is going to be to tell the jury that we've changed, we're different from what we used to be, so I want to know all the ways that you think Philip Morris has changed from the way you used to be.

- A. It's my intention to tell the jury how we run the business today, so I'm going to be talking about the things that we do in terms of how we operate the business today. I don't really know how to describe for you what's changed. I think the jury will make the decision as to what they perceive is different.

In enumerating the various changes the company had made, Szymanczyk identified the website as one item he would be highlighting.

\section{Fending off racketeering charges}

Another crucial venue for Philip Morris to employ its evolved stance on causation and addiction was in the US government's recent racketeering trial against all of the major tobacco companies for conspiracy to sell a product without disclosing the harmful consequences to its customers and engaging in massive consumer fraud. ${ }^{34}$ Philip Morris executives' comments in the public media have left little doubt that the website was conceived partially to give the company the ability to say that it had changed its ways and did not constitute a dangerous threat of future bad behaviour, a key issue in the enforcement of the Racketeer Influenced and Corrupt Organizations Act ("RICO"). ${ }^{35}$ A 22 September 2004 Philip Morris press release claimed that the public saw "substantial proof of how the tobacco industry has changed when it presented its evidence in the federal tobacco trial." ${ }^{\prime 36}$ In the press release, Michael Pfiel, vice president of corporate communications for Altria Group (Philip Morris's parent corporation), referring to the website's language, stated "You simply can't ignore the breadth and depth of changes the tobacco industry has made in its business practices, and nothing the government can say in court will alter that fact." It may not be a coincidence that Philip Morris launched its website within a few weeks of the United States's filing of its RICO case.

One of Philip Morris's lead attorneys in the RICO case, Theodore Wells, made an opening statement that argued that the law required a judicial finding not only that fraud had occurred, but also that it probably would continue. ${ }^{37}$ Wells asserted that "it would be impossible to demonstrate the likelihood of future fraud because the industry now runs ads and makes information available on its Web sites detailing the hazards of smoking and the addictive nature of nicotine." Wells stated that "[i]t's an unambiguous and clear message ..." and asserted that the company's statements "are of a permanent, irreversible and everlasting nature." Wells encouraged the court to look at Philip Morris's present conduct, stating, "The 
government says to the court, 'Focus on the past.' The defence says to the court, 'Focus on the present.' Which one is a better predictor of the future?" He decried the government's dismissal of Philip Morris's recent public relations efforts because of past marketing transgressions, stating that "to say that they were part of some RICO enterprise and that token changes were too little too late. . . I respectfully suggest that this is simply not fair." ${ }^{\prime 38}$ Similar statements were carried in all of the major media outlets including the Wall Street Journal, Reuters Wire Service and all major metropolitan newspapers.

Despite the tobacco industry's arguments, on 17 August 2006, Judge Gladys Kessler found in United States $v$ Philip Morris, Inc, et $a l^{39}$ that Philip Morris, along with the other tobacco defendants, had violated the RICO Act. ${ }^{35}$ More specifically, Judge Kessler found that Philip Morris used its website as a vehicle for violating the RICO statute 39 at 884 to make fraudulent statements about nicotine manipulation ${ }^{39}$ at 382 and addiction. 39 at 926 She stated "Philip Morris's current website claims that the company's position on addiction is the same as the public health community's but Philip Morris's statement on addiction omits the material information that nicotine delivered by cigarettes is a drug and that is addictive." 39 at 926 Because she found that through their website, as well as other media outlets, the tobacco defendants "continue to make affirmative statements on smoking and health issues that are fraudulent," 39 at 926 she ordered the tobacco defendants to issue corrective statements using the same forums. The corrective statements must state that "nicotine and cigarette smoking are addictive," that the tobacco defendants "do manipulate the design of cigarettes in order to enhance the delivery of nicotine," and that there are adverse health effects of smoking, including "all the diseases which smoking has been proven to cause." 39 at 928

\section{DISCUSSION}

Philip Morris's website is constructed in a manner whereby very little original text commits it to any firm position that cannot be explained or rationalised in a court of law. Rather, it has a heavy emphasis on directing readers to other public health websites. In this way, Philip Morris can appear to be in closer alignment with the prevailing view on smoking and disease and addiction held by its customers, the general public, public health authorities and regulators, while still maintaining what Balbach et al refer to as its freedom to "believe" whatever it wants to about the dangers of its products, and to dispute vociferously in court the very sources of information to which it refers its website visitors.

With its website and advertising campaign, Philip Morris tried to convey the message that it had reformed the way it does business and was merely publicising its earnest efforts at corporate responsibility. However, analysis of Philip Morris employees' statements in interviews, internal documents and transcripts from personal injury trials and the RICO case make it clear that Philip Morris had no intention of truly changing its position on smoking and disease issues in the arena in which it counted most - the court of law. Internal documents by Philip Morris executives show that the change in Philip Morris's stance was a calculated one aimed at improving its public image in order to survive in a societal and litigation environment that is increasingly hostile to an industry that purveys deadly products, a tactic that is increasingly common among corporations in general, not just tobacco companies. ${ }^{40}$ Philip Morris tried to curry public favour by appearing to concede to and agree with the warning messages issued by public health officials and scientists. Its efforts are aimed at appearing responsible, rather than actually being responsible. Its strategy seems to be aimed at creating the perception that its corporate behaviour has improved by using carefully parsed language while actually conceding nothing at all.

At the same time, however, Philip Morris executives admitted in both the press and in court depositions and testimony that they would continue to employ the same legal strategies as they had in the past, arguing the lack of causation between the plaintiff's injuries and the use of Philip Morris's cigarettes, and denying that cigarettes are addictive. Despite the employment of the societal alignment strategy that disingenuously elevates image over substance, this paper's findings show that the tobacco industry has not changed its fundamental legal strategy of denying the conclusions of the same public health officials to whom it refers its website visitors, despite its public relations campaign. A recent study by Milberger et al bears out this theory and has affirmed that Philip Morris and the other tobacco companies have not changed their litigation strategies despite the change in the rhetoric voiced by their websites and advertising campaigns. ${ }^{41}$

In analysing Philip Morris's motivation for its shift in message, one could conclude that Philip Morris chose to take a gamble that the risk of exposure of its new company line's hypocrisy was less harmful than the gains it would achieve in influencing potential jurors, judges and governmental regulators. One perceived payoff for Philip Morris in changing its position was to deter juries from awarding punitive damages in individual smokers' suits, though the data show that this has not been a consistently winning tactic, with several unprecedented, enormous punitive damages awards being handed down in the last several years. Another reason for the "we've changed" makeover was demonstrated in the RICO suit. Philip Morris and the other tobacco defendants urged the judge not to punish them for past bad conduct, but rather to look at their improved conduct in the present, of which their websites and supposedly concessionary statements contained therein were prime examples. They tried to persuade Judge Kessler that there exists a whole new industry culture, particularly since the signing of the Master Settlement Agreement between the state attorneys general and the tobacco industry, and the launching of websites and advertising campaigns such as that of Philip Morris. Judge Kessler was not convinced and rejected this view, finding that the tobacco companies are racketeers who have used their websites and advertising campaigns to defraud their consumers and the public and will continue to do so without certain corrective remedies. ${ }^{42}$

This paper shows that Philip Morris has not yet actually come into alignment with society in both words and deeds despite its use of new language on its website and in its advertising. A day of reckoning might be at hand if the corrective statements remedy Judge Kessler ordered in the RICO case, which will force Philip Morris and the tobacco industry to tell the truth about the harm and addiction its products cause, using the same media forums that it used to disseminate its fraudulent statements, is upheld on appeal. Perhaps only under the duress of a court order will Philip Morris finally and truly inform the public about the dangers and addictiveness of smoking its products.

\section{What this paper adds}

This study reveals the public relations motivation behind Philip Morris's purported change in its stance on smoking and health and addiction, as represented by its website's language, and unmasks its unchanged position in litigation. 


\section{ACKNOWLEDGEMENTS}

The author would like to thank her colleagues Professor Richard A Daynard, Marlo Miura and Jess Alderman for their invaluable editorial assistance.

This work has been supported by NIH grant RO1 CA 87571 .

Competing interests: None.

\section{REFERENCES}

1 Balbach E, Smith E, Malone R. How the health belief model helps the tobacco industry: individuals, choice, and "information". Tob Control 2006;15(suppl 4):iv37-iv43.

2 Hwang S. Philip Morris promises to polish its image. Financial Express 7 July 1999, viewed at http://www.financialexpress.com/old/fe/daily/19990707/ fco07053.html.

3 http://www.philipmorrisusa.org/.

4 Philip Morris. "Why discuss tobacco issues?" 18 Oct 1999. Bates: $521543246-$ 521543261. http://tobaccodocuments.org/rir/521543246-3261.html.

5 http://www.philipmorrisusa.org/About Us - TV Advertisements (viewed 25 March 2005)

6 Philip Morris Companies Inc. "Philip Morris Expands Efforts to Communicate More Openly with the Public" 13 Oct 1999. Bates: $2082966060-2082966063$. http://tobaccodocuments.org/pm/2082966060-6063.html.

7 "Trial testimony of Denise F Keane, January 19, 2005 [am], United States of America v Philip Morris USA Inc." 19 Jan 2005. http://tobaccodocuments.org/ datta/KEANED011905AM.html at 10566-10575.

8 "Trial testimony of Denise F Keane, January 19, 2005 [pm], United States of America v Philip Morris USA Inc." 19 Jan 2005. http://tobaccodocuments.org/ datta/KEANED01 1905PM.html at 10620.

9 ABC News: Nightline, Steven Parrish, Philip Morris, discusses company's new web site and where company stands now compared to nine years ago, 13 October 1999 (viewed on Lexis/Nexis).

10 http://www.philipmorrisusa.org/Health Issues, Cigarette Smoking and Disease In Smokers (viewed 25 March 2005) (emphasis added).

11 Deposition of James J Morgan in Whiteley v. Raybestos-Manhattan Inc. 20 Feb 2000. http://tobaccodocuments.org/datta/MORGANJ022000.html.

12 Deposition of Ellen Merlo in Whiteley v Raybestos-Manhattan Inc, 22 Mar 2000. http://tobaccodocuments.org/datta/MERLOE032200.html.

13 Tobacco Products Liability Project. Individual plaintiff victories-tobacco litigation, 31 December 2003, viewed at http://www.tobacco.neu.edu/ litigation/resources/victories.htm.

14 Douglas C, Davis R, Beasley K. Epidemiology of the third wave of tobacco litigation in the United States, 1994-2005. Tob Control 2006;15(suppl 4):iv9-iv16.

15 Tobacco Products Liability Project. Attorney who has never lost a trial against big tobacco returns to the courtroom and wins in retrial of lung cancer case, background and commentary on the compensatory damages verdict, 3 May 2007, viewed at http://www.tobacco.neu.edu/litigation/cases/ Backgrounders/Whiteley2_compensatory.htm.

16 Deposition of Michael E Szymanczyk in Engle v RJ Reynolds Tobacco Co, 10 May 2000. http://tobaccodocuments.org/datta/SZYMANCZYKM051000.html.

17 Acosta HM. "Robert R Jones, Plaintiff, Vs Brown \& Williamson Tobacco Corporation, Defendants. Request for Admissions to Defendant Philip Morris Incorporated. Case No: 97-4966". Oct 1999. Bates: 20723650062072365010. http://tobaccodocuments.org/pm/2072365006-5010.html.

18 Acosta H. Personal communication (on file with PHAI).

19 Dyckman M. "Philip Morris' 'admissions' a word dance." St Petersburg Times 24 Oct 1999. Bates: 2072365660B-2072365661. http://tobaccodocuments.org/ $\mathrm{pm} / 2072365660 \mathrm{~B}-5661 . \mathrm{html}$.
20 Waisbren BA. "The Estate of Lillian C Hazeltine, Plaintiff V Maureen Norman, $M D$, Defendants. Plaintiff's request for judicial notice as to the health consequences of smoking and the addictive potential of cigarettes. CA No 99$11549^{\prime \prime}$. Oct 1999 (est). Bates: 83536494. hitp://tobaccodocuments.org/lor/ 83536494.html.

21 Waisbren B. Waisbren, BA, JR. "Hiscock v The Tobacco Institute, Inc, et al." 19 Nov 1999. Bates: 2072364957. http://tobaccodocuments.org/pm/ 2072364957.html.

22 Defendant closing statment, October 2, 2002, Bullock v Philip Morris Inc. 02 Oct 2002. http://tobaccodocuments.org/datta/DCSBULLOCK100202.html.

23 Tobacco Products Liability Project. Media backgrounder: California jury finds Philip Morris liable.... again!, September 26, 2002, viewed at http:// www.tobacco.neu.edu/litigation/cases/Backgrounders/bullock1.htm.

24 Presumed corporate author, Philip Morris. "Goals: where do we HAVE to be in the year 2000?" 19920204/R. Bates: 2024705949-2024705981. http:// tobaccodocuments.org/landman/2024705949-5981.html.

25 Deposition of Ellen Merlo in Boeken v Philip Morris Inc. 03 May 2001. http:// tobaccodocuments.org/datta/MERLOE050301PM.html.

26 Philip Morris. "Steven C Parrish Lausanne 990607". 07 Jun 1999 (est). Bates: 2085250082-2085250093. http://tobaccodocuments.org/pm/20852500820093.html.

27 Poole J. "Michigan Dairy Dialog Remarks". 23 Feb 2000. Bates: 20784705362078470556. http://tobaccodocuments.org/landman/20784705360556.html.

28 Trial Testimony of Ellen Merlo in Boeken v Philip Morris Inc. 03 May 2001. $\mathrm{http}$ ///tobaccodocuments.org/datta/MERLOE050301AM.html.

29 Tobacco Products Liability Project. Media backgrounder and commentary: Los Angeles jury rejects new Philip Morris defense and issues $\$ 28$ billion punitive damages verdict against tobacco giant, 4 October 2002, viewed at http:// www.tobacco.neu.edu/litigation/cases/Backgrounders/bullock2.htm.

30 Tobacco Products Liability Project. Media backgrounder \& commentary: California judge reduces amount of punitive damages but keeps the heat on Philip Morris, 9 August 2001, viewed at http://www.tobacco.neu.edu/ litigation/cases/Backgrounders/boeken2.htm.

31 Engle et al $\vee$ Liggett Group, Inc, et al. 2006 Fla. LEXIS, 1480.

32 "Trial testimony of Ellen Merlo, March 22, 2000, Whiteley V RaybestosManhattan Inc." 22 Mar 2000. http://tobaccodocuments.org/datta/ MERLOE032200.html.

33 Tobacco Products Liability Project. Backgrounder: California appeals court reverses \$21. 72 million verdict and Remands Whiteley case for new trial on technicality, 8 April 2004 viewed at http://www.tobacco.neu.edu/litigation/ cases/Backgrounders/Whiteley_Reversed.htm.

34 United States v Philip Morris, Inc, et al. Complaint, Sept 22, 1999. http:// www.usdoj.gov/civil/cases/tobacco2/complain.pdf.

3518 USC §§ 1961-1968.

36 Philip Morris USA points to a significantly changed industry and a future shaped by the present, not the distant past, as trial begins in Federal Court, 22 September 2004. http://www.philipmorrisusa.com/en/pressroom/content/ press_release/articles/pr_september_22_2004_pmupscifspndptbfc.asp.

37 Zuckerbrod N. "Tobacco industry lawyers deny fraud. "Associate Press Newswires, 22 Sept, 2004.

38 Janofsky M. Lawyers start their defense of tobacco. New York Times Section A, column 6, 23 Sept, 2004:22.

39 United States v Philip Morris, Inc, et al, 449 F. Supp.2d 1 (DDC 2006).

40 Sharp Paine L. Value shift: why companies must merge social and financial imperatives to achieve superior performance. New York: McGraw-Hill, 2003.

41 Milberger S, Davis RM, Douglas CE, et al. Tobacco manufacturers' defence against plaintiffs' claims of cancer causation: throwing mud at the wall and hoping some of it will stick. Tob Control 2006;15(suppl 4):iv17-iv26.

42 Guardino S, Banthin C, Daynard R. Tobacco Control Resource Center, USA v Philip Morris USA, Inc, et al. Analysis of Judge Kessler's Final Opinion and Order, Updated 2 April 2007, viewed at http://www.tobacco.neu.edu/ litigation/cases/DOJ/doj_opinion_summary.pdf. 